\title{
ANALISIS STRUKTUR TEKS EKSPOSISI PADA KARYA SISWA KELAS X ADMINISTRASI PERKANTORAN SMK NEGERI 1 JAMBI
}

\author{
Nurfadillah Sugiarti $^{1}$, Sainil Amral ${ }^{2}$, Sumiharti $^{3}$ \\ Program Studi Pendidikan Bahasa dan Sastra Indonesia, \\ Fakultas Keguruan dan Ilmu Pendidikan, Universitas Batanghari, \\ Jambi
}

\author{
Sandicute37@yahoo.com \\ sainilamral@yahoo.com \\ harti.sumi@yahoo.com
}

\begin{abstract}
The purpose of this research is to describe the students ability in writing exposition text at class XAdministrasi Perkantoran 1 SMK Negeri 1 Kota Jambi Academic Year $2017 / 2018$. This research is qualitative descriptive. The primary data of the research is students exposition text. The data is collected by using documentation technique. The sample is taken by using simple random sampling technique. The result of the research shows that there are 24 students who wrote exposition text by using good thesis structure, there are 27 students who wrote exposition text by using good sequences of argument, and there are 27 students who wrote exposition text by using good repetition. Based on the result of the research, it can be concluded that, in general, students ability in writing exposition text at class XAdministrasi Perkantoran 1 SMK Negeri 1 falls into good criteria.
\end{abstract}

Key Words: exposition text, texts structure

\footnotetext{
${ }^{1}$ Mahasiswa Program Studi Pendidikan Bahasa dan Sastra Indonesia, Fakultas Keguruan dan Ilmu Pendidikan, Universitas Batanghari, Jambi

${ }^{2}$ Dosen Program Studi Pendidikan Bahasa dan Sastra Indonesia, Fakultas Keguruan dan Ilmu Pendidikan, Universitas Batanghari ,Jambi

${ }^{3}$ Dosen Program Studi Pendidikan Bahasa dan Sastra Indonesia, Fakultas Keguruan dan Ilmu Pendidikan, Universitas Batanghari, Jambi
}

Analisis Struktur Teks Eksposisi pada Karya Siswa Kelas X Administrasi Perkantoran SMK Negeri 1 Jambi 


\begin{abstract}
Abstrak
Tujuan penelitian ini adalah mendeskripsikan kemampuan menulis teks eksposisi siswa kelas X Administrasi Perkantoran 1 SMK Negeri 1 Kota Jambi Tahun Ajaran 2017/2018. Jenis penelitian yang digunakan adalah deskriptif kualitatif. Data utama penelitian ini berupa karya siswa berupa teks eksposisi. Teknik Pengumpulan data yang digunakan adalah teknik dokumentasi. Pengambilan sampel dilakukan dengan teknik simple random sampling. Hasil penelitian menunjukkan bahwa terdapat 24 siswa menulis teks eksposisi dengan menggunakan struktur tesis yang baik, terdapat 27 siswa menulis teks eksposisi dengan rangkaian argumen yang baik, dan terdapat 27 siswa menulis teks ekposisi dengan penegasan ulang yang baik. Selain itu, terdapat juga siswa yang tidak menggunakan struktur tesis, rangkaian argumen, dan penegasan ulang dalam menulis teks eksposisi. Berdasarkan hasil penelitian dapat disimpulkan bahwa secara umum kemampuan siswa kelas X Administrasi Perkantoran 1 SMK Negeri 1 dalam menulis teks eksposisi adalah baik.
\end{abstract}

Kata Kunci : teks eksposisi, struktur teks

\section{PENDAHULUAN}

Struktur merupakan syarat yang diperlukan dalam penulisan teks eksposisi. Struktur tersebut merupakan tata organisasi dari sebuah teks yang tersusun dengan baik. Kegiatan pembelajaran bahasa Indonesia, tidak lepas dari keterampilan berbahasa. Hamalik (2008:57) mengatakan, "Pembelajaran adalah suatu kombinasi yang terususun meliputi unsur-unsur manusiawi, material, fasilitas, perlengkapan, dan prosedur yang saling mempengaruhi mencapai tujuan pembelajaran. Untuk menulis teks eksposisi, perlu diawali dengan teks dan penulisannya yang baik. Teks dapat dimediakan secara tulis atau lisan dengan organisasi tertentu untuk mengungkapkan makna lebih luas. Dalam pembelajaran bahasa Indonesia, apa yang dimaksudkan teks tidak lebih dari himpunan huruf yang membentuk kata dan kalinat yang dirangkai dalam sistem yang terdapat pada teks tersebut.

Keterampilan menulis merupakan keterampilan berbahasa yang kompleks. Kompleksitas terletak pada tuntutan kemampuan untuk menata dan mengorganisasikan ide secara runtut dan logis, serta menyajikan dalam ragam bahasa tulis dan kaidah penulisannya. Oleh karena itu, proses menulis memiliki beberapa tahapan yang memberi nama keseluruhan tulisan. Menurut Dalman 
(2014:15-20),“Tahapan menulis terdiri dari tahapan prapenulisan, tahap penulisan, dan tahap pasca penulisan".

Fenomena sosial yang terjadi mengenai teks eksposisi, banyak kesulitan yang dialami oleh siswa. Berdasarkan pengamatan dari penulis, siswa kurang memahami dalam pembuatan teks eksposisi. Penulis melakukan pengamatan pada tanggal 14 Agustus setelah surat penelitian di buat dan penulis melakukan observasi terhadap siswa. Alasan penulis memilih penelitian tentang struktur teks eksposisi, pada saat penulis melakukan penelitian langsung ke lapangan di temukan beberapa siswa mengalami kesulitan untuk membuat teks eksposisi. Selain itu, penulis memilih untuk mengambil struktur teks eksposisi karena beberapa siswa dalam membuat karangan eksposisi, belum memahaminya.

Penelitian mengenai struktur teks eksposisi dilaksanakan di SMK Negeri 1 Kota Jambi. Alasan penulis memilih lokasi ini karena menurut peneliti sekolah ini sangat layak untuk dijadikan penelitian selain itu lokasi sekolah ini sangat strategis dan akses untuk menuju ke sekolah tersebut sangat mudah. Guru-guru yang ada di sekolah tersebut sangat baik dan mau membantu. Sekolah ini juga merupakan tempat dimana penulis melakukan kegiatan Praktek Pengalaman Lapangan (PPL). Penulis mendapatkan kesempatan mengajar selama 3 bulan di sana di kelas X Administrasi Perkantoran 1. Penulis memilih kelas $\mathrm{x}$ administrasi perkantoran 1 karena siswa-siswi tersebut mempunyai respon yang sangat baik dan selalu semangat dalam belajar bahasa Indonesia.

Berdasarkan uraian di atas, dapat diidentifikasi beberapa masalah yang muncul dalam menganalisis teks eksposisi diantararnya isi, struktur teks, kosakata, kalimat, dan mekanik. Adapun yang menjadi tujuan penelitian ini adalah untuk mendeskripsikan struktur teks eksposisi pada karya siswa kelas $\mathrm{x}$ administrasi perkantoran 1 SMK Negeri 1 Kota Jambi. Berdasarkan tujuan penelitian di atas maka manfaat penelitian ini dibagi menjadi dua, yaitu manfaat praktis dan manfaat teoretis. Secara teoretis, hasil penelitian ini dapat memberikan kontribusi terhadap teori tentang struktur teks eksposisi yang mendukung konsepkonsep dasar mengenai teks eksposisi. Sedangkan manfaat praktis penelitian ini adalah, agar bermanfaat bagi beberapa pihak di antaranya : (1) bagi guru sebagai bahan pertimbangan dalam upaya 
peningkatan siswa untuk terampil dalam menulis teks eksposisi, (2) bagi peneliti lainnya, dapat dijadikan sebagai acuan bagi pembanding peneliti yang lain dalam membuat teks eksposisi.

\section{METODE PENELITIAN}

Jenis penelitian yang digunakan dalam penelitian ini adalah penelitian kualitatif dengan menggunakan pendekatan deskriptif. Riyanto (1996:23) menyatakan "Pendekatan deskriptif adalah yang diarahkan untuk mmeberikan gejalagejala, fakta-fakta, atau kejadian-kejadian secara sistematis dan akurat mengenai sifat-sfat populasi atau daerah tertentu. Penelitian kualitatif juga mengandalkan uraian deskriptif, kata, atau kalimat yang disusun secara cermat dan sistematis mulai dari penghimpunan data, menafsirkan dan melaporkan hasil penelitian. Penelitian ini mendeskripsikan kemampuan menulis teks eksposisi pada karya siswa kelas $\mathrm{X}$ administrasi perkantoran 1 tahun ajaran 2017/2018.

Populasi dalam penelitian ini adalah keseluruhan siswa kelas $\mathrm{x}$ administrasi perkantoran 1 SMK Negeri 1 Kota Jambi sebanyak 30 orang. Penentuan sampel dalam penelitian ini adalah sebagian hasil karya siswa kelas $\mathrm{x}$ administrasi perkantiran 1 SMK Negeri 1 Kota Jambi dan penulis hanya mengambil 10 karya siswa dari 30 siswa. Penentuan sampel dilakukan dengan menggunakan teknik simple radom sampling. Dikatakan simple (sederhana) karena pengambilan sampel dari populasi dilakukan secara acak tanpa memperhatikan strata yang ada di dalam populasi.

Teknik pengunpulan data dalam penelitian ini adalah dengan menggunakan teknik observasi, dan dokumentasi. Observasi dalam penelitian ini dilakukan sengan cara pengamatan secara langsung terhadap siswa mengenai pembuatan struktur teks eksposisi pada karya siswa. Sedangkan pada metode dokumentasi, peneliti hanya mengumpulkan beberapa data tentang tulisan karya siswa, membaca buku teks mengenai teks eksposisi, mencatat dan memilih bagian-bagian yang ada di dalam struktur teks, dan setelah data terkumpul penulis menganalisis struktur teks eksposisisi.

Analisis data merupakan kegiatan yang sangat penting dalam penelitian. Untuk menjelaskan atau menafsirkan suatu data dalam sebuah penelitian seorang peneliti juga memerlukan beberapa argumentasi, rujukan, dan bandingan yang bersumber dari buku- 
buku bacaan. Analisis data dalam penelitian ini bersifat deskriptif kualitatif. Hal ini dikarenakan objek yang diteliti berupa data-data yang memerlukan penjelasan secara deskriptif. Adapun kegiatan menganalisis data dalam penelitian ini seperti yang diungkapkan oleh Miles and Huberman dalam Sugiyono (2013:246), sebagai berikut: (1) Reduksi data yaitu merangkum, memilah hal-hal yang pokok, memfokuskan pada hal-hal yang penting. Tujuan utama dalam penelitian ini adalah menganalisis struktur teks eksposisi pada karya siswa kelas $\mathrm{x}$ SMK Negeri 1 Kota Jambi. Maka dari itu, dari seluruh karangan siswa akan diberi skor pada setiap pembuatan teks eksposisi. (2) Data display yaitu dalam melakukan penelitian dalam bentuk uraian singkat.

\section{HASIL DAN PEMBAHASAN}

Data yang ada dalam penelitian ini adalah tentang analisis struktur teks eksposisi pada karya siswa kelas $\mathrm{x}$ administrasi perkantoran 1 SMK Negeri 1 Kota Jambi Tahun Ajaran 2017/2018. Hasil penelitian tentang analisis struktur teks eksposisi pada karya siswa kelas $\mathrm{X}$ Administrasi Perkantoran 1 dapat diketahui pada saat siswa mengerjakan tugas dalam keadaan kondusif. Siswa sangat merespon dan bersemangat dalam pembelajaran mengenai teks eksposisi. Berikut ini disajikan hasil penilaian kegiatan belajar dua orang siswa yang memperoleh nilai tertinggi dan siswa yang memperoleh nilai terendah.

Tabel 1. Hasil Penilaian Kegiatan Pembelajaran Teks Eksposisi

\begin{tabular}{lllccc}
\hline No. & Nama Siswa & \multicolumn{1}{c}{$\begin{array}{c}\text { Aspek Penilaian } \\
\text { (Struktur Teks) }\end{array}$} & $\begin{array}{c}\text { Nilai } \\
\text { Angka }\end{array}$ & $\begin{array}{c}\text { Nilai } \\
\text { Huruf }\end{array}$ & Predikat \\
1. $\begin{array}{l}\text { Angga } \\
\text { Nichoalas }\end{array}$ & $\begin{array}{l}\text { Tesis. Rangkaian argumen, } \\
\text { dan penegasan ulang } \\
\text { Tesis. Rangkaian argumen, } \\
\text { dan penegasan ulang }\end{array}$ & 84 & A & baik sekali \\
2. & Erlangga & 66 & $\mathrm{C}$ & cukup \\
\hline
\end{tabular}


Tabel 2. Hasil Analisis Karya Siswa tentang Struktur Teks Eksposisi

\begin{tabular}{|c|c|c|c|c|c|}
\hline \multirow[t]{2}{*}{ No. } & \multirow{2}{*}{$\begin{array}{l}\text { Nama } \\
\text { Siswa }\end{array}$} & \multicolumn{3}{|c|}{ Struktur Teks Eksposisi } & \multirow[b]{2}{*}{ Analisis } \\
\hline & & Tesis & $\begin{array}{c}\text { Rangkaian } \\
\text { Argumen }\end{array}$ & $\begin{array}{c}\text { Penegasan } \\
\text { Ulang }\end{array}$ & \\
\hline 1. & $\begin{array}{l}\text { Angga } \\
\text { Nicholas }\end{array}$ & $\begin{array}{l}\text { Banjir yang terjadi } \\
\text { di mana-mana yang } \\
\text { menyebabkan } \\
\text { banjir adalah hujan } \\
\text { deras, buang } \\
\text { sampah di selokan, } \\
\text { dan lain-lain. }\end{array}$ & $\begin{array}{l}\text { Banjir yang } \\
\text { terjadi di } \\
\text { pedesaan, di } \\
\text { kota-kota, di } \\
\text { sungai, } \\
\text { danau, dan } \\
\text { got pun bisa } \\
\text { menjadi } \\
\text { banjir karena } \\
\text { orang } \\
\text { membuang } \\
\text { sampah } \\
\text { sembarangan. }\end{array}$ & $\begin{array}{l}\text { Banjir adalah } \\
\text { bencana alam } \\
\text { dan sering terjadi } \\
\text { di pedesaan, di } \\
\text { kota-kota, di } \\
\text { sungai, danau } \\
\text { dan got pun bisa } \\
\text { menjadi banjir } \\
\text { karena orang } \\
\text { membuang } \\
\text { sampah } \\
\text { sembarangan. }\end{array}$ & $\begin{array}{l}\text {-Bagian tesis yang di buat oleh } \\
\text { angga nicholas sudah sangat } \\
\text { baik dan tersusun rapi. } \\
\text {-Bagian rangkaian argumen yang } \\
\text { dibuat oleh siswa ini: sudah } \\
\text { tersusun dengan baik, } \\
\text { penyusunan kalimatnya mudahh } \\
\text { dipahami. } \\
\text { - penegasan ulang yang ada } \\
\text { dalam teks eksposisi ini sudah } \\
\text { tertata dengan baik sehingga } \\
\text { mudah dipahami saat membaca } \\
\text { teks eksposisi tersebut. }\end{array}$ \\
\hline 2. & Erlangga & $\begin{array}{l}\text { Saat ini sering kita } \\
\text { lihat di televisi } \\
\text { banyak berita } \\
\text { tentang tawuran } \\
\text { antar sekolah yang } \\
\text { menyebabkan } \\
\text { korban jiwa. Bukan } \\
\text { hanya sekali, tetapi } \\
\text { sangat sering berita } \\
\text { seperti itu di } \\
\text { tayangkan. }\end{array}$ & Tidak ada & $\begin{array}{l}\text { Jadi, menurut } \\
\text { saya kenakalan } \\
\text { remaja adalah } \\
\text { merusak diri } \\
\text { sendiri dan dapat } \\
\text { merugikan orang } \\
\text { lain. }\end{array}$ & $\begin{array}{l}\text { Bagian tesisnya sudah tepat, } \\
\text { penyusunan kalimatnya kurang } \\
\text { terorganisasi, tetapi ide utama } \\
\text { dalam teks tersebut sangat baik. } \\
\text { Rangkaian argumen yang di buat } \\
\text { oleh siswa pada teks eksposisi, } \\
\text { tidak dicantumkan. Siswa } \\
\text { langsung menuju bagian } \\
\text { kesimpulan. Pendapat-pendapat } \\
\text { penulis mengenai teks eksposisi } \\
\text { tersebut tidak ada. }\end{array}$ \\
\hline
\end{tabular}

\section{SIMPULAN}

Hasil penelitian dan pembahasan mengenai struktur teks eksposisi pada karya siswa kelas $\mathrm{x}$ administrasi perkantoran 1 SMK Negeri 1 Kota Jambi Tahun Ajaran 2017/2018, yaitu ada beberapa siswa yang membuat struktur teks yang tidak lengkap. Diantaranya, yang tidak membuat tesis dalam teks eksposisinya sebanyak 1 orang siswa, yang tidak membuat rangkaian argumen dalam teks eksposisinya sebanyak 1 orang siswa, dan yang tidak membuat penegasan ulang dalam teks eksposisinya sebanyak 3 orang siswa. Pada saat pembuatan teks eksposisi, ada beberapa siswa yang tidak mecantumkan strukturnya dengan lengkap dan belum tertata dengan rapi. Dalam pelaksanaannya, siswa mengalami beberapa kendala saat membuat teks eksposisi, menempatkan struktur teks, seperti tesis, rangkaian argumen, dan penegasan ulang. Dalam hal ini, guru dituntut untuk dapat memotivasi siswanya agar lebih memahami mengenai pembuatan struktur teks eksposisi dengan 
baik. Kendala yang lain juga ditemukaan pada siswa saat menentukan ide dalam mengembangkan tulisannya dalam pembuatan teks eksposisi. Mengenai hal ini guru sebaiknya membantu siswa dengan memberikan arahan-arahan yang membuat siswa kembali terpacu untuk memperluas ide-ide yang ada dalam tulisannya.

\section{DAFTAR PUSTAKA}

Dalman. (2014). Keterampilan Menulis. Jakarta: PT RajaGrafindo Persada.

Hamalik, Oemar. (2011). Kurikulum dan Pembelajaran. Jakarta: Bumi Aksara.

Riyanto, Yatim. (2001). Metodologi Penelitian Pendidikan. Surabaya: SIC.

Sugiyono. (2013). MetodePenelitian Kuantitatif Kualitatif dan $R \& D$. Bandung: Alfabeta. 